\title{
Escherichia coli Molybdoenzymes Can Be Activated by Protein FA from Several Gram-negative Bacteria
}

\author{
By CLAIRE-LISE SANTINI, ${ }^{1}$ DORIS KARIBIAN, ${ }^{1}$ ANIL VASISHTA, ${ }^{2}$ \\ DAVID BOXER ${ }^{2}$ AND GERARD GIORDANO ${ }^{1 *}$ \\ ${ }^{1}$ Laboratoire de Structure et fonction des Biomembranes (LCB), Centre National de la Recherche \\ Scientifique, Département de Biologie, Faculté de Sciences de Luminy, 13288 Marseille Cedex 9. \\ France \\ ${ }^{2}$ Department of Biochemistry, University of Dundee, Dundee DD1 4HN, UK
}

(Received 15 December 1988; revised 5 July 1989; accepted 19 September 1989)

\begin{abstract}
Six Gram-negative bacteria (Klebsiella pneumoniae, Erwinia chrysanthemi, Proteus vulgaris, Serratia marescens, Salmonella typhimurium, and Pseudomonas aeruginosa) were shown to contain an FA-type protein capable of activating aponitrate reductase, apotrimethylamine $\mathrm{N}$-oxide reductase and apoformate dehydrogenase of Escherichia coli. Protein FA activity was highest in Erwinia chrysanthemi and lowest in Pseudomonas aeruginosa. All the species also contained the low- $M_{\mathrm{r}}(\leq 1500)$ heat-resistant material previously reported to be necessary for the protein-FAdependent activation of $E$. coli chlB nitrate reductase.
\end{abstract}

\section{INTRODUCTION}

Respiratory nitrate reductase (EC 1.7.99.4) is found in many Gram-positive and Gramnegative bacteria (Pichinoty et al., 1969), and the enzyme has been characterized in several different genera, e.g. Micrococcus (Forget, 1971; Rosso et al., 1983), Klebsiella (Van't Riet \& Planta, 1975), Escherichia coli (Enoch \& Lester, 1975; MacGregor, 1975), Pseudomonas (Radcliffe \& Nicholas, 1970), Proteus (Oltman et al., 1976) and Bacillus (Kiszkiss \& Downey, 1972). However, assembly of the enzyme has been studied mainly in E. coli, partly because of the advanced knowledge of the genetics of this bacterium.

The isolation of chlorate-resistant ( $c h l)$ mutants of $E$. coli by Puig et al. (1967) provided a means for studying the assembly of active respiratory nitrate reductase and other molybdoenzyme complexes since, by incubating a mixture of inactive extracts of $\mathrm{chl}$ mutants, such as $c h l A$ and $c h l B$, nitrate reductase activity is obtained (Azoulay \& Puig, 1968). This in vitro complementation was shown to depend on the contribution, by each extract, of activities that are defective in the other extract. In this way, components involved in the biosynthesis of active nitrate reductase, namely aponitrate reductase subunits, proteins FA and PA, the molybdenum cofactor and low $-M_{\mathrm{r}}$ substances distinct from the molybdenum cofactor, have been identified, (Rivière et al., 1975; Grillet \& Giordano, 1983; Rolfe \& Onodera, 1972; Glaser \& DeMoss, 1971; Johnson \& Rajagopalan, 1987; Boxer et al., 1987). In the case of complementation between extracts of $\operatorname{chl} A$ and $\operatorname{chlB}$ mutants, the $\operatorname{chl} A$ extract provides protein FA which is lacking in $c h l B$ mutants and the $c h l B$ extract provides protein PA which is absent from the $c h l A$ extract.

The addition of purified protein FA to extracts of $c h l B$ mutants leads to the activation of nitrate reductase (Rivière et al., 1975). Recently, we have described a quantitative assay for protein FA activity and have shown that this activity is constitutively expressed in $E$. coli (Low et al., 1988). Since protein FA is actively expressed in all classes of $c h l$ mutants except $c h l B$ it is probably the product of the $\operatorname{chlB}$ gene.

We report here the in vitro activation of nitrate reductase in an $E$. coli chlB mutant by extracts of six Gram-negative bacteria. All of them contained protein FA activity. 


\section{Table 1. Nitrate reductase activities in crude extracts of bacteria}

Crude extracts were prepared from cells grown anaerobically with nitrate as described in Methods.

\begin{tabular}{|c|c|c|c|}
\hline Strain & Source & $\begin{array}{l}\text { Relevant } \\
\text { genotype }\end{array}$ & $\begin{array}{c}\text { Nitrate reductase } \\
\text { activity } \\
{\left[\mu \mathrm{mol} \mathrm{NO}_{3}^{-} \text {reduced } \mathrm{min}^{-1}\right.} \\
\left.(\mathrm{mg} \text { protein })^{-1}\right]\end{array}$ \\
\hline $\left.\begin{array}{l}\text { Escherichia coli } \text { PA601 } \\
\text { Escherichia coli AP24 } \\
\text { Escherichia coli AP15 } \\
\text { Klebsiella pneumoniae } 52.145 \\
\text { Serratia marcescens } 5389 \\
\text { Proteus vulgaris } 5860 \\
\text { Pseudomonas aeruginosa } \text { PAO25 } \\
\text { Erwinia chrysanthemi } 3739 \\
\text { Salmonella typhimurium } \text { LT2 } \\
\text { Salmonella typhimurium LCB1 } \\
\text { Salmonella typhimurium } \text { LCB69 } \\
\text { Salmonella typhimurium } \text { LCB8 }\end{array}\right\}$ & $\begin{array}{l}\text { This } \\
\text { laboratory } \\
\text { Institut Pasteur, } \\
\text { Paris, France } \\
\text { A. Lazdunski* } \\
\text { J. P. Chambost* } \\
\text { M. Chippaux }\end{array}$ & $\begin{array}{l}\text { Wild-type } \\
\text { chlB } \\
\text { chlA } \\
\text { Wild-type } \\
\text { chlA } \\
\text { chlB } \\
\text { chlE }\end{array}$ & $\begin{aligned} & 0.9 \\
& \leqslant 0.001 \\
& \leqslant 0.001 \\
& 1.79 \\
& 0.97 \\
& 1.14 \\
& 0.3 \\
& 0.920 \\
& 1.12 \\
& \leqslant 0.003 \\
& \leqslant 0.001 \\
& \leqslant 0.006\end{aligned}$ \\
\hline
\end{tabular}

* LCB-CNRS, 31 Chemin Joseph Aiguier, 13009 Marseille, France.

\section{METHODS}

Growth of bacteria and preparation of subcellular fractions. The bacteria used, listed in Table 1, were grown in the medium of Giordano et al. (1978), which contain glucose, yeast extract (Difco), Bacto-peptone (Difco) $\left(2 \mathrm{~g} \mathrm{l}^{-1}\right.$ of $^{-}$ each) and $1 \mu \mathrm{M}$-sodium molybdate. Nitrate reductase was induced with $1 \mathrm{~g} \mathrm{KNO}_{3} \mathrm{l}^{-1}$. Sodium molybdate in the medium was replaced by $10 \mathrm{~mm}$-sodium tungstate as indicated. For anaerobic growth, closed vessels were filled almost to the top with medium and incubated without shaking. For aerobic growth, cultures were incubated in 2 litre Fernbach flasks containing $500 \mathrm{ml}$ of medium with shaking. Cultures were grown at $32^{\circ} \mathrm{C}$ and harvested at the mid- to late-exponential phase. The bacteria were washed twice by centrifugation with $50 \mathrm{~mm}-\mathrm{Tris} / \mathrm{HCl}$, pH 7.6, containing $1 \mathrm{~mm}$-benzamidine. $\mathrm{HCl}$ and subsequently used immediately or stored at $-80^{\circ} \mathrm{C}$.

Bacteria were ruptured in a French pressure cell at $69 \mathrm{MPa}$ and cell debris was removed by centrifugation at $18000 \mathrm{~g}$ for $25 \mathrm{~min}$ to give the crude extract. Since the latter was very concentrated $\left(20 \mathrm{mg}\right.$ protein $\left.\mathrm{ml}^{-1}\right)$ it was necessary to centrifuge it twice at $120000 \mathrm{~g}$ for $90 \mathrm{~min}$ to obtain a soluble fraction free of membrane vesicles. All operations were done at $4{ }^{\circ} \mathrm{C}$. Heat-treated extracts were prepared as described previously (Boxer et al., 1987). Samples ( $1 \mathrm{ml} ; 30 \mathrm{mg}$ protein) of the crude extract were boiled for $8 \mathrm{~min}$ under nitrogen. Suspensions were centrifuged at $18000 \mathrm{~g}$ for $15 \mathrm{~min}$ to yield a clear supernatant which was used immediately.

Activation of nitrate reductase. This was done according to Azoulay et al. (1969) by incubating crude extracts of $E$. coli chlB with a source of protein FA (soluble fraction or purified FA). Incubations were done under $\mathrm{N}_{2}$ at $32^{\circ} \mathrm{C}$ for the times indicated and the reaction stopped by cooling to $0^{\circ} \mathrm{C}$. Soluble fractions prepared for testing protein FA activity were made from cells grown aerobically without nitrate. One unit of protein FA activity produces a nitrate reductase activity of $1 \mathrm{nmol} \mathrm{NO}_{3}{ }^{-}$reduced $\min ^{-1}$ per min of incubation period in the presence of excess $\mathrm{chlB}$ soluble fraction under the conditions described (Low et al., 1988).

Heat treatment of protein $F A$. Samples $(5 \mu \mathrm{l})$ of partially purified protein FA (approximately 700 protein FA units $\mathrm{ml}^{-1}$ ) were boiled in a water-bath for $5-200 \mathrm{~s} ; 50 \mu \mathrm{l}$ (1 mg protein) of chlB strain (AP24) soluble fraction was then added and the mixture made up to $100 \mu \mathrm{l}$ with $50 \mathrm{mM}$-Tris/ $\mathrm{HCl}, \mathrm{pH} \mathrm{7.6}$. Nitrate reductase was assayed after incubation at $32^{\circ} \mathrm{C}$ for $10 \mathrm{~min}$.

Trypsin treatment of protein $F A$. Samples $(5 \mu \mathrm{l})$ of partially purified protein FA (as above) were incubated with $10 \mu \mathrm{l}$ trypsin $\left(1 \mu \mathrm{g} \mathrm{ml}^{-1}\right.$; bovine pancreas type III, Sigma) at $30^{\circ} \mathrm{C}$ for $30-200 \mathrm{~s}$. Trypsin was inactivated by the addition of $10 \mu \mathrm{l}$ soya-bean trypsin inhibitor $\left(10 \mathrm{mg} \mathrm{ml}^{-1}\right.$; type II-S, Sigma). To this mixture $50 \mu \mathrm{l}$ of the soluble fraction of $c h l B$ was added, the volume made up to $100 \mu 1$ with buffer and the mixture incubated at $30^{\circ} \mathrm{C}$ for $10 \mathrm{~min}$ before nitrate reductase was assayed. Controls were done by incubating trypsin with its inhibitor prior to protein FA addition, followed by the $c h l B$ fraction.

Enzyme assays. Nitrate reductase activity was measured by the spectrophotometric method of Jones \& Garland (1977), based on the oxidation of reduced benzyl viologen, coupled to the reduction of nitrate to nitrite. Trimethylamine $N$-oxide reductase activity was measured with $10 \mathrm{mM}$-trimethylamine $N$-oxide instead of nitrate. Benzyl-viologen-linked formate dehydrogenase activity was assayed spectrophotometrically by following the reduction of benzyl viologen coupled to the oxidation of formate as described by Enoch \& Lester (1975) 
Table 2. Nitrate reductase activating ability of extracts of different bacteria

Nitrate reductase activities (expressed as $\mu \mathrm{mol} \mathrm{NO}_{3}^{-}$reduced $\mathrm{min}^{-1}$ ) were measured, after $30 \mathrm{~min}$ incubation at $32^{\circ} \mathrm{C}$ under $\mathrm{N}_{2}$, in a mixture $(1 \mathrm{ml})$ containing an excess of $E$. coli chlB crude extract ( $20 \mathrm{mg}$ protein) and a limiting concentration of either soluble fraction ( $4 \mathrm{mg}$ protein) or partially purified activating extract from the bacteria listed.

\begin{tabular}{lccc}
\multicolumn{1}{c}{ Strain } & $\begin{array}{c}\text { Column eluate } \\
\text { reductase* }\end{array}$ & $\begin{array}{c}\text { Activating } \\
\text { activity† }\end{array}$ & Protein $\ddagger$ \\
E. coli & 120 & 130 & $5 \cdot 1$ \\
Salmonella typhimurium & 48 & 50 & $3 \cdot 4$ \\
Proteus vulgaris & 80 & 120 & $3 \cdot 5$ \\
Erwinia chrysanthemi & 160 & 170 & $2 \cdot 9$ \\
Pseudomonas aeruginosa & 0 & 7 & $2 \cdot 2$ \\
Klebsiella pneumoniae & 90 & 80 & $4 \cdot 9$ \\
Serratia marcescens & 100 & 80 & $3 \cdot 0$
\end{tabular}

\footnotetext{
* Nitrate reductase activating activity of $100 \mathrm{mg}$ soluble-extract protein of $E$. coli chlB.

$\dagger$ Total nitrate reductase activating activity recovered after gel filtration of $100 \mathrm{mg}$ soluble fraction from the strain indicated.

$\ddagger$ Total protein (mg) of active fractions after gel filtration on Sephadex G-75.
}

\section{RESULTS}

\section{Nitrate reductase activity in Gram-negative bacteria}

The presence of $E$. coli protein FA can be demonstrated by its ability to activate aponitrate reductase in extracts of $c h l B$ mutants. At zero-time such assay mixtures should contain little or no nitrate reductase activity. Therefore, to look for protein FA activity in different bacteria we chose species that were likely to have nitrate reductase activity only when grown anaerobically in the presence of nitrate and not when grown aerobically in the absence of nitrate (Table 1).

All strains used had benzyl-viologen-linked nitrate reductase activity when grown anaerobically with nitrate. Klebsiella pneumoniae, the most active strain, had six times the activity of Pseudomonas aeruginosa, the least active strain. Under aerobic conditions, nitrate reductase activity in all the bacteria tested was less than $0.06 \mu \mathrm{mol}$ nitrate reduced $\mathrm{min}^{-1}(\mathrm{mg}$ protein $)^{-1}$.

\section{Protein FA activity in soluble fractions of bacteria}

Soluble fractions of all bacterial strains tested activated aponitrate reductase in crude extracts of $E$. coli chlB (Table 2). Mixtures containing active nitrate reductase were centrifuged and supernatants passed through a $1.5 \mathrm{~m}$ column of Biogel A. Analysis of column fractions with antiserum developed against $E$. coli nitrate reductase showed that the activated enzyme originated from $E$. coli (Giordano et al., 1980) (results not shown).

The activation process (Fig. 1) reached a plateau at an activity of $4.8 \mu \mathrm{mol} \mathrm{NO}_{3}$ - reduced $\mathrm{min}^{-1} \mathrm{ml}^{-1}$. Activation rates depended on the source of the soluble fraction added to the $E$. coli extract. Extracts of Erwinia chrysanthemi and Pseudomonas aeruginosa were the most and least active, respectively (Fig. 1). Extracts of some of the bacteria, and particularly Salmonella typhimurium, when used in low concentration, showed a lag period before reaching their maximum activation rates (results not shown). With Serratia marcescens a lower plateau was attained.

These results indicate that one or several compounds in the soluble fraction of the bacteria tested can activate aponitrate reductase in $E$. coli chlB. They are thus similar to protein FA of $E$. coli.

\section{Similarity to protein $\mathrm{FA}$ of the activating compound from different bacteria}

$M_{\mathrm{r}}$. As a first step towards characterizing the activator(s) in soluble fractions of the different bacteria, we estimated its apparent $M_{\mathrm{r}}$ by gel filtration. This procedure also gave a partial purification. Fractionation of soluble fractions of $E$. coli or its $\operatorname{chlA}$ mutant on Sephadex G-75 


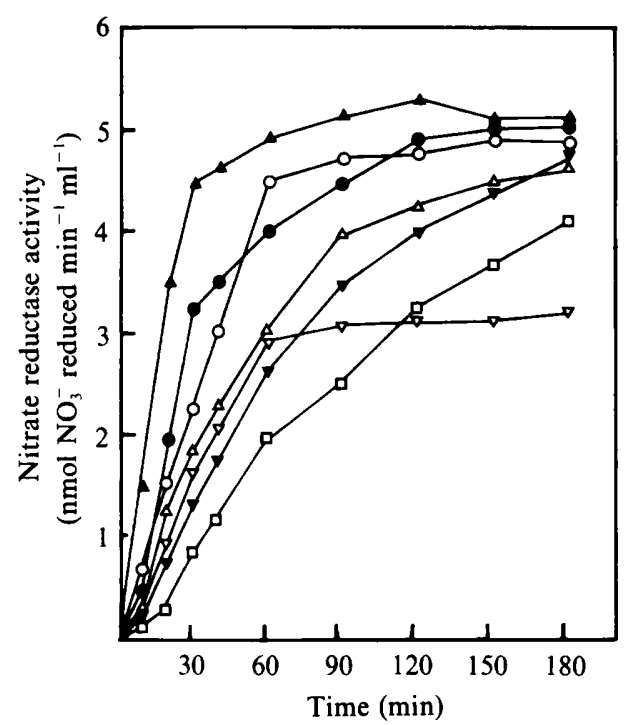

Fig. 1. Kinetics of nitrate reductase activation by the soluble fractions from different bacteria. $E$. coli chlB was grown anaerobically in nitrate-containing medium. The other bacteria were grown aerobically without nitrate. The activation assay mixtures $(1 \mathrm{ml})$ contained $E$. coli chlB crude extract $(20 \mathrm{mg}$ protein) and the soluble fraction from another bacterium ( $P$. aeruginosa, $10 \mathrm{mg}$ protein; others $2.5 \mathrm{mg}$ ). $\square$, Pseudomonas aeruginosa; $\nabla$, Salmonella typhimurium; $\nabla$, Serratia marcescens; $\Delta$, Erwinia chrysanthemi; $\bigcirc$, Klebsiella pneumoniae; $\bullet, E$. coli; $\triangle$, Proteus vulgaris.

gave high yields of protein FA activity. In previous studies protein FA was purified about 20fold (Rivière et al., 1975; Low et al., 1988). The apparent $M_{\mathrm{r}}$ of protein FA estimated by this method was about 18000 (Fig. 2) which is half that reported by Rivière et al. (1975).

Fractionation of the soluble fractions from cells of the different bacteria gave similar activity profiles consistent with a similar $M_{\mathrm{r}}$ for the active substances (Fig. 2). The yields ranged from 70 to over $100 \%$ of the activity applied to this column with 18 to 43 -fold purification (Table 2). For Proteus vulgaris, the total amount of $c h l B$ nitrate reductase activating activity recovered from the column was significantly greater than that measured in the original supernatant, suggesting that this extract contains an inhibitor of the activation process. With the exception of Pseudomonas aeruginosa there was a less than $3 \cdot 5$-fold variation in protein FA specific activity among the six species tested (Table 2).

Sensitivity to heat or trypsin treatment. Partially purified protein FA of $E$. coli is very sensitive to heat. Its ability to activate nitrate reductase in $c h l B$ was destroyed by boiling for 25 to $30 \mathrm{~s}$. Protein FA is also very sensitive to the action of trypsin : exposure to $0 \cdot 1 \mathrm{mg} \mathrm{ml}^{-1}$ for $10 \mathrm{~s}$ caused $98 \%$ inactivation. The partially purified activators obtained from the six other species of bacteria were similarly sensitive to heat and to trypsin treatment suggesting that they too are proteins.

Activation of other molybdoenzymes by the nitrate reductase activator. Giordano et al. (1984) showed that protein FA of $E$. coli was able to activate precursors of trimethylamine $N$-oxide reductase (EC 1.6.6.9), (benzyl-viologen-dependent), formate dehydrogenase (EC 1.2.-.-) and nitrate reductase. Partially purified activators of the other bacterial species could activate these enzymes to levels similar to, or higher than, that found with protein FA of E. coli (Table 3).

Activation of E. coli chlB nitrate reductase as a function of activator concentration. The rate of nitrate reductase activation increased linearly as a function of the concentration of partially purified FA or other activator (Fig. 3). Activation rates varied depending on the source of the activator. For Pseudomonas aeruginosa relatively large amounts of the activator preparation were necessary to attain the activation plateau. Experiments with soluble fractions instead of 


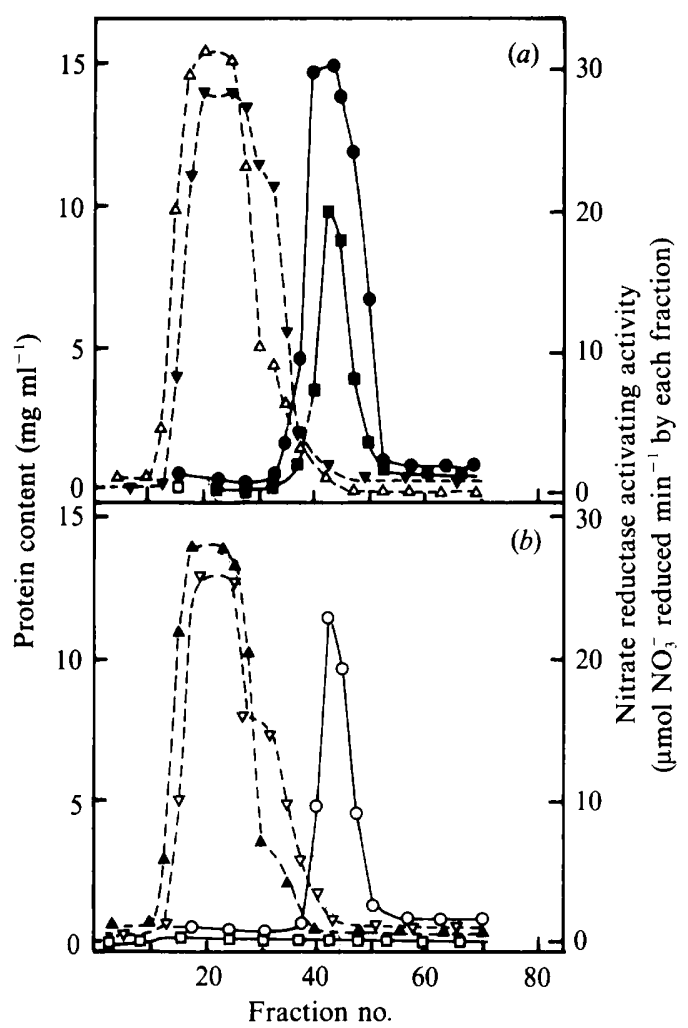

Fig. 2. Fractionation of protein FA activity in extracts of $E$. coli and Salmonella typhimurium. Soluble fractions $(100 \mathrm{mg}$ protein) obtained from wild-type cells of $E$. coli and $S$. typhimurium (a) or from various chl mutants of $S$. typhimurium $(b)$ were applied to a Sephadex G-75 Superfine column $(2.5 \times 80 \mathrm{~cm})$, equilibrated and eluted with $20 \mathrm{~mm}$-Tris $/ \mathrm{HCl}, \mathrm{pH} 7 \cdot 6,0.25 \mathrm{M}-\mathrm{NaCl}, 1 \mathrm{~mm}-$ benzamidine at $4{ }^{\circ} \mathrm{C}$. Samples of the fractions $(0.2 \mathrm{ml})$ were incubated for $30 \mathrm{~min}$ with the crude extract of $E$. coli chlB $(20 \mathrm{mg}$ in $1 \mathrm{ml}$ total volume). Protein: $E$. coli wild-type $(\triangle)$; $S$. typhimurium wild-type $(\nabla) ; S$. typhimurium chlA $(\nabla) ; S$. typhimurium chlB (A). Nitrate reductase activity: $E$. coli wild-type $(\bullet) ; S$. typhimurium wild-type $(\square) ; S$. typhimurium chlA (O); S. typhimurium chlB ( $\square)$.

\section{Table 3. Activation of molybdoenzymes by protein $F A$ from different bacteria}

Complementation was done as described in Methods. Mixtures $(0.5 \mathrm{ml})$ containing $0.2 \mathrm{mg}$ partially purified protein FA and $4 \mathrm{mg}$ crude extract of $E$. coli chlB grown under inducing conditions (Giordano et al., 1984) were incubated for $90 \mathrm{~min}$ at $32^{\circ} \mathrm{C}$. Trimethylamine $N$-oxide reductase and nitrate reductase activities are expressed as nmol TMAO or $\mathrm{NO}_{3}^{-}$reduced $\min ^{-1} \mathrm{ml}^{-1}$. Benzyl-viologendependent formate dehydrogenase activity is expressed as nmol formate oxidized $\mathrm{min}^{-1} \mathrm{ml}^{-1}$.

$\begin{array}{lccr}\begin{array}{c}\text { Source of } \\ \text { protein FA }\end{array} & \text { Nitrate reductase } & \begin{array}{c}\text { Trimethylamine } \\ \text { N-oxide reductase }\end{array} & \begin{array}{c}\text { Formate } \\ \text { dehydrogenase }\end{array} \\ \text { No protein FA added } & \leqslant 1 & \leqslant 1 & \leqslant 1 \\ \text { E. coli } & 880 & 320 & 124 \\ \text { Klebsiella pneumoniae } & 780 & 280 & 80 \\ \text { Salmonella typhimurium } & 860 & 320 & 68 \\ \text { Proteus vulgaris } & 920 & 520 & 144 \\ \text { Erwinia chrysanthemi } & 980 & 800 & 132 \\ \text { Pseudomonas aeruginosa } & 720 & 280 & 86 \\ \text { Serratia marcescens } & 280 & 140 & 60\end{array}$

partially purified preparations gave similar results. There was a linear relationship between the amount of $E$. coli $\mathrm{chlB}$ extract and activation of nitrate reductase. Activation stopped upon depletion of aponitrate reductase or any other required compounds in the $E$. coli chlB extracts (observed with crude as well as partially purified activator). These results show that a compound similar to protein FA of $E$. coli is present in soluble fractions of the various bacteria. 


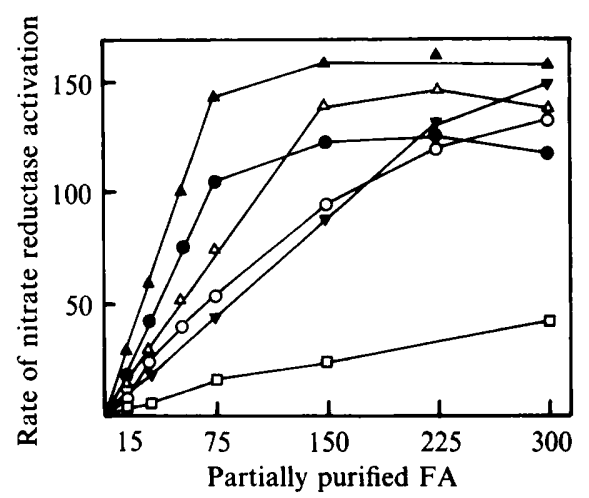

Fig. 3. Rate of nitrate reductase activation as a function of source and concentration of protein FA. Protein FA preparations from the soluble fraction of bacteria grown aerobically as described in Fig. 1 were purified by gel filtration on Sephadex G-75 Superfine. The assay mixtures contained $1 \mathrm{ml}$ crude extract ( $20 \mathrm{mg}$ protein) of $E$. coli chlB and various amounts of protein FA. Nitrate reductase activity was measured after $15 \mathrm{~min}$ of incubation. The rate of nitrate reductase activation is expressed in protein FA units as described in Methods. $\boldsymbol{\Delta}$, Erwinia chrysanthemi; $\bullet, E$. coli; 0 , Klebsiella pneumoniae; $\boldsymbol{\nabla}$, Salmonella typhimurium; $\square$, Pseudomonas aeruginosa; $\triangle$, Proteus vulgaris.

\section{Nitrate reductase activation by crude extracts of chl mutants of Salmonella typhimurium}

Mutants of $S$. typhimurium, termed $\operatorname{chlA}$, chlB and $\operatorname{chlE}$ by analogy with the $E$. coli genome (Casse et al., 1972; Casse, 1973) were examined for protein FA activity (Fig. 2). All possessed a protein of about $18 \mathrm{kDa}$ able to activate nitrate reductase of $E$. coli chlB with the exception of the $S$. typhimurium chlB strain. This confirms the existence of protein FA in $S$. typhimurium and shows that protein FA activity is absent only from $\operatorname{chlB}$ strains as has been shown for $E$. coli (Low et al., 1988).

\section{Presence of low- $M_{\mathrm{r}}$ factors necessary for activation}

In $E$. coli one or more thermostable compounds of low $M_{\mathrm{r}}(\leqslant 1500)$, together with protein FA, are required for activation of $c h l B$ nitrate reductase (Boxer et al., 1987), as shown by the inability of protein FA to activate $E$. coli $\mathrm{chlB}$ extract that has been depleted of low- $M_{\mathrm{r}}$ material by passage through a Sephadex G-25 column. Activation ability is restored by addition of a deproteinized (heat-treated) extract from the soluble fraction of the wild-type or $c h l$ strains. The proteins FA of the different bacteria studied here were also active in this system and gave comparable levels of activation (data not shown).

To see whether the various bacteria studied also contained the low- $M_{\mathrm{r}}$ material essential for $E$. coli $\operatorname{chl} B$ nitrate reductase activation, desalted $E$. coli $\operatorname{chl} B$ soluble fractions were incubated with $E$. coli protein FA, together with heated, clarified extract prepared from one of the other bacteria. All the bacteria tested contained the active fraction (Table 4). In all cases the active compound(s) had an apparent $M_{\mathrm{r}} \leqslant 1500$ on a Sephadex G-50 column. Moreover, as for $E$. coli, the compound could be distinguished from the molybdenum cofactor by the fact that heated extracts of cells grown in the presence of tungstate, an antagonist of molybdate, were also active (Saracino et al., 1986; Giordano et al., 1987; Amy \& Rajagopalan, 1979; Scott et al., 1979).

\section{Activation of nitrate reductase in extracts of $E$. coli chlB grown in the presence of tungstate}

Heated, clarified extracts of $E$. coli contain the molybdenum cofactor which can, together with protein FA, activate nitrate reductase in extracts of $\mathrm{chlB}$ grown anaerobically in tungstatecontaining medium (Saracino et al., 1986). Protein FA preparations obtained fron the different species were tested in this system and were found to be active, although Pseudomonas aeruginosa protein FA had a notably weaker activity (result not shown). 
Table 4. Activation of $E$. coli chlB nitrate reductase by heat-treated fractions from different bacteria

\begin{abstract}
Assay mixtures $(0.5 \mathrm{ml})$ for nitrate reductase activation contained $0.2 \mathrm{mg}$ partially purified protein FA from $E$. coli, $0 \cdot 3 \mathrm{ml}$ of one of the heat-treated fractions and either $4 \mathrm{mg}$ protein from $E$. coli chlB soluble extract excluded by Sephadex G-25 (chlB; G-25) or 4 mg crude-extract protein from $E$. coli chlB grown in the presence of $10 \mathrm{~mm}$-tungstate ( $\mathrm{chlB}$; tungstate). Heat-treated fractions of bacteria were prepared as described in Methods. Incubations were for $90 \mathrm{~min}$ at $32^{\circ} \mathrm{C}$. Nitrate reductase activities are expressed as percentages of the activity $\left(860 \mathrm{nmol} \mathrm{NO}-\mathrm{Neduced}_{3} \mathrm{~min}^{-1} \mathrm{ml}^{-1}\right)$ in an assay mixture containing $0.2 \mathrm{mg}$ protein FA and $4 \mathrm{mg} E$. coli chlB crude extract.
\end{abstract}

Nitrate reductase activity (\%)

Source of heat-treated extract after incubation with:

No extract added

E. coli

E. coli*

Salmonella typhimurium

Proteus vulgaris

Erwinia chrysanthemi

Pseudomonas aeruginosa

Klebsiella pneumoniae

Serratia marcescens

\begin{tabular}{cc}
\multicolumn{2}{c}{$\begin{array}{c}\text { Nitrate reductase activity }(\%) \\
\text { after incubation with: }\end{array}$} \\
$\overbrace{c h l B ;} ;$ G-25 & ; tungstate \\
2 & 3 \\
78 & 80 \\
3 & 2 \\
49 & 48 \\
62 & 36 \\
64 & 55 \\
27 & 38 \\
71 & $48 \cdot 5$ \\
Not determined & 61 \\
rotein FA added. &
\end{tabular}

In parallel with the above experiment, heat-treated extracts of the six species were tested for activity in a system containing protein FA from $E$. coli plus an extract of $E$. coli chlB grown in tungstate-containing medium. All extracts gave similar activation of nitrate reductase suggesting that they possessed active molybdenum cofactor (Table 4). This was confirmed by complementation of the aponitrate reductase in extracts of induced Neurospora crassa nit-1 (Ketchum et al., 1970). The identity of the active substance in heat-treated extracts with active molybdenum cofactor was further supported by analysis of Sephadex G-50 filtrates for activity in both the $N$. crassa nit- 1 and tungstate-grown $E$. coli chlB complementation assays. The elution profiles of the activities were indistinguishable from one another and were similar to that reported previously for $E$. coli (Saracino et al., 1986). Clearly, molybdenum cofactor activity is present in heat-treated extracts of all the bacteria examined.

\title{
DISCUSSION
}

All the species examined contained protein FA similar to that of $E$. coli, molybdenum cofactor activity and the small, heat-stable material necessary for activation of $E$. coli chlB nitrate reductase.

Nitrate reductase activation by in vitro complementation of extracts of different $c h l$ mutants was first studied by Azoulay \& Puig (1968). This work led to the discovery that proteins FA and PA were required for activation of molybdoenzymes (Rivière et al., 1975; Grillet \& Giordano, 1983). More recently, Boxer et al. (1987) showed that one or more thermoresistant compounds, distinct from the molybdenum cofactor, were required for activation of nitrate reductase.

Using aerobically grown cells as a source of protein FA in the activation system described previously (Rivière et al., 1975; Low et al., 1988), we have shown that a protein FA also exists in other Gram-negative bacteria, and that activation of molybdoenzymes in these bacteria requires protein FA along with the molybdenum cofactor and a thermoresistant compound(s). The molybdenum cofactor from the bacteria examined also functioned in the in vitro activation of an E. coli molybdoenzyme.

Comparison of the genetic maps of E. coli and Salmomella typhimurium reveals that the genes involved in chlorate resistance ( $c h l A, c h l B, c h l E)$ are in the same relative positions (Bachmann, 
1983; Sanderson \& Roth, 1983). Until now, there was no indication that $c h l$ genes localized in the same position in these two organisms encoded proteins with the same functions. Our results show a correlation in $S$. typhimurium between protein FA activity and the chlB locus, as has been shown for $E$. coli. Since protein FA in $E$. coli is almost certainly the product of the chlB gene (Low et al., 1988) the same presumably applies to $S$. typhimurium.

Rivière et al. (1975) reported that, after several purification steps, protein FA of $E$. coli had an $M_{\mathrm{r}}$ of 35000 . Their purified protein tended to polymerize. The one purification step we used (gel filtration) did not lead to polymerizátion and yielded a value of 18000 for the $M_{\mathrm{r}}$. We assume that the value reported earlier was that of the dimeric form.

The rate of nitrate reductase activation by partially purified protein FA is directly related to the protein FA activity present (Low et al., 1988). However, since all the parameters of activation are not yet known, the possibility that the active fraction contains compounds other than protein FA which play a role in activation cannot be eliminated. In this respect, it should be noted that nitrate reductase of Klebsiella pneumoniae differs significantly from that of $E$. coli in the configuration of its subunits in the membrane (Abraham et al., 1981).

This work was supported by the Centre National de la Recherche Scientifique (CNRS) and the Science and Engineering Research Council (SERC).

\section{REFERENCES}

Abraham, P. A., Boxer, D. H., Graham, A., Tucker, A. D., Van't Riet, J. \& Wientues, F. B. (1981). Immunochemical and structural comparison of the respiratory nitrate reductase fron Escherichia coli and Klebsiella aerogenes. FEMS Microbiology Letters 10 , 95-100.

AMY, N. K. \& Rajagopalan, K. V. (1979). Characterization of molybdenum cofactor from Escherichia coli. Journal of Bacteriology 140, 114-124.

Azoulay, E. \& Puig, J. (1968). Reconstitution of enzymatically active particles from inactive soluble elements in Escherichia coli K12. Biochemical and Biophysical Research Communications 33, 1019-1024.

Azoulay, E., Puig, J. \& Couchoud-Beaumont, P. (1969). Reconstitution in vitro de l'activité nitrate réductase particulaire chez Escherichia coli K12. Biochimica et biophysica acta 237, 579-590.

BaChmanN, B. (1983). Linkage map of Escherichia coli. Microbiological Reviews 47, 180-230.

Boxer, D. H., Low, D. C., Pommier, J. \& Giordano, G. (1987). Involvement of a low-molecular weight substance in the in vitro activation of the molybdoenzyme respiratory nitrate reductase from a $\mathrm{chlB}$ mutant of Escherichia coli. Journal of Bacteriology 169, 4678-4685.

CASSE, F. (1973). Etudes génétiques de mutants bactériens ayant perdu les activités catalytiques d'une ou plusieurs enzymes d'oxydo-réduction spécifiques à la vie anaérobie. Doctoral thesis AO7027, Université AixMarseille II, France.

Casse, F., Pascal, M. C., Chippaux, M. \& RatouchNIAK, J. (1972). Mapping of the chlB gene in Salmonella typhimurium LT2. Molecular and General Genetics 119, 67-70.

ENOCH, H. G. \& LESTER, R. L. (1975). The purification and properties of formate dehydrogenase and nitrate reductase from Escherichia coli. Journal of Biological Chemistry 250, 6693-6705.

FORGET, P. (1971). Les nitrate réductases bactériennes. Solubilisation, purification et propriétés de l'enzyme A de Micrococcus denitrificans. European Journal of Biochemistry 18, 442-450.
Giordano, G., Graham, A., Boxer, D. H. \& Azoulay, E. (1978). Characterisation of the membrane-bound nitrate reductase activity of aerobically grown chlorate-sensitive mutants of Escherichia coli K12. FEBS Letters 43, 290-294.

Giordano, G., Grillet, L., Pommier, J., Terriere, C., Haddock, B. A. \& Azoulay, E. (1980). Precursor forms of the subunits of nitrate reductase in chlA and chlB mutants of Escherichia coli $\mathrm{K} 12$. European Journal of Biochemistry 105, 297-306.

Giordano, G., Violet, M., Medani, C. L. \& Pommier, J. (1984). A common pathway for the activation of several molybdoenzymes in Escherichia coli K12. Biochimica et biophysica acta 798, 216-225.

Giordano, G., Santini, C. L., Saracino, L. \& Iobbi, C. (1987). Involvement of protein with the molybdenum cofactor in the in vitro activation of nitrate reductase from a chlA mutant of Escherichia coli $\mathrm{K} 12$. Biochimica et biophysica acta 914, 220-232.

Glaser, J. H. \& DeMoss, J. A. (1971). Phenotypic restoration by molybdate of nitrate reductase activity in chlD mutants of Escherichia coli K12. Journal of Bacteriology 108, 854-860.

Grillet, L. \& Giordano, G. (1983). Identification and purification of a protein involved in the activation of nitrate reductase in the soluble fraction of a chlA mutant of Escherichia coli K12. Biochimica et biophysica acta 749, 115-124.

Johnson, M. E. \& Rajagopalan, K. V. (1987). Involvement of $\operatorname{chl} A, E, M$ and $N$ loci in Escherichia coli molybdopterin biosynthesis. Journal of Bacteriology 169, 117-125.

Jones, R. W. \& Garland, P. B. (1977). Sites and specificity of the reaction of pyridilium compounds with anaerobic respiratory enzymes of Escherichia coli. Biochemical Journal 164, 199-211.

Ketchum, P. A., Cambier, H. Y., Frazier, W. A., MADANSKY, C. H. \& Nason, A. (1970). In vitro assembly of Neurospora assimilatory nitrate reductase from protein subunits of Neurospora mutant, and xanthine oxidizing or aldehyde oxidase systems of higher animals. Proceedings of the National 
Academy of Sciences of the United States of America 66, 1016-1023.

Kiszkiss, P. F. \& Downey, R. T. (1972). Localization and solubilization of the respiratory nitrate reductase of Bacillus stearothermophilus. Journal of Bacteriology 109, 803-810.

Low, D. C., Pommier, J., Giordano, G. \& Boxer, D. H. (1988). Biosynthesis of molybdoenzymes in Escherichia coli: chlB is the only chlorate-resistance locus required for protein FA activity. FEMS Microbiology Letters 49, 331-336.

MaCGregor, C. H. (1975). Anaerobic cytochrome b in Escherichia coli: association with and regulation of nitrate reductase. Journal of Bacteriology 121, 11111116.

Oltmann, L. F., Reijnders, W. N. M. \& Stouthamer, A. H. (1976). Characterisation of purified nitrate reductase $\mathrm{A}$ and chlorate reductase $\mathrm{C}$ from Proteus mirabilis. Archives of Microbiology 111, 25-35.

Pichinoty, F., Azoulay, E., Couchoud-Beaumont, P., LEMINor, L., Rigano, C., Bigliardi-Rouvier, J. \& Piechaud, M. (1969). Recherche des nitrate réductases bactériennes A et B: Résultats. Annales de l'Institut Pasteur 116, 27-42.

Puig, J., Azoulay, E. \& Pichinoty, F. (1967). Étude génétique d'une mutation à effet pléiotropique chez Escherichia coli. Compte rendu de l'Académie des sciences 264, 1507-1509

RADCliffe, B. L. \& Nicolas, D. H. (1970). Some propeties of a nitrate reductase from Pseudomonas denitrificans. Biochimica et biophysica acta 205, 273-287.
Rivière, C., Giordano, G., Pommier, J. \& Azoulay, E. (1975). Membrane reconstitution in chlr mutants of Escherichia coli K12. VII. Purification and properties of the FA factor, the product of the $c h l B$ gene. Biochimica et biophysica acta 389, 219-235.

Rolfe, B. \& ONODERA, K. (1972). Genes, enzymes and membrane proteins of the nitrate respiration system of Escherichia coli. Journal of Membrane Biology 9 , 195-207.

Rosso, J. P., Forget, P. \& Pichinoty, F. (1973). Les nitrate réductases bactériennes: solubilisation et propriétés de l'enzyme A de Micrococcus halodenitrificans. Biochimica et biophysica acta 321, 443-455.

SANDERSON, K. E. \& RoTH, J. (1983). Linkage map of Salmonella typhimurium. Microbiological Reviews 47, 410-453.

Saracino, L., Violet, M., Boxer, D. H. \& Giordano, G. (1986). Activity in vitro of respiratory nitrate reductase of Escherichia coli $\mathrm{K} 12$ grown in the presence of tungstate. Involvement of molybdenum cofactor. European Journal of Biochemistry 158, 483-490.

SCOTT, R. H., SPERL, G. T. \& DeMoss, J. A. (1979). In vitro incorporation of molybdate into demolybdoproteins in Escherichia coli. Journal of Bacteriology 137, 719-726.

Van't Riet, J. \& Planta, R. J. (1975). Purification, structure and properties of respiratory nitrate reductase of Klebsiella aerogenes. Biochimica et biophysica acta 379, 81-94. 